\title{
Different catalysts for new polyols for rigid PUR-PIR foams
}

\author{
Joanna Liszkowska*, Bogusław Czupryński, Joanna Paciorek-Sadowska \\ Kazimierz Wielki University, Bydgoszcz, Poland \\ "Corresponding author: e-mail: liszk@ukw.edu.pl
}

\begin{abstract}
New polyols were synthesized with 2-hydroxypropane-1.2.3-tricarboxylic acid and butane-1,4-diol (1.4-BD). The synthesis was performed using different catalysts in the amount of $0.1 \%$. Used catalyst: Tyzor TPT, tin(II) acetate, sulfuric(IV) acid. The fourth reaction was conducted without the use of a catalyst. The polyols' properties were evaluated with regards to the usefulness in rigid polyurethane-polyisocyanurate (PUR-PIR) foams (acid value, density, $\mathrm{pH}$ and solubility, FTIR spectra). Based on the research, it was evaluated that only the polyol synthesized using Tyzor TPT (E6) was useful in production of rigid PUR-PIR foams. Its hydroxyl number was $496 \mathrm{mgKOH} / \mathrm{g}$ and its viscosity was about $14552 \mathrm{mPa} \cdot \mathrm{s}$. A series of five foams P6.1-P6.5 was produced with this polyol. Rigid foams test results indicated that the amount of this compound in the foam substantially affects its compressive strength, density and their retention. The foams have low brittleness values.
\end{abstract}

Keywords: polyurethane foam, butanediol, 2-hydroxypropane-1.2.3-tricarboxylic acid, viscosity, TG.

\section{INTRODUCTION}

The modification of polyol and using different types of polyols for polyurethane synthesis gives different type of products with with various properties, e.g. elastomers, rigid foams, elastic foams and other. This raw material became irreplaceable in many aspects of life ${ }^{\mathbf{1 , 2}}$. Polyols used for polyurethanes should be cheap but should also improve their properties, e.g. decreased combustibility. That is why researches are still being conducted to achieve lower costs of producing polyurethanes and improve their properties ${ }^{3-6}$. Polyols should also be eco-friendly. Their waste disposal and recycling are very important issues $^{7-10}$ and the incombustible of materials ${ }^{5,11-12}$. Vegetable oil-based polyols were produce ${ }^{13-18}$. A systematic study substituting polyether polyol with palm kernel oil based polyester polyol in rigid polyurethane foam studied Septevani A. A. at all. ${ }^{19}$ Currently, coating materials are primarily prepared from petroleum-based materials to eliminate organic solvents from paints and coatings ${ }^{20}$. Green polyurethane from lignin and soybean oil through non-isocyanate reactions was produced by Lee and Deng $^{21}$. On the basis of bio-polyols are produced polyurethanes named bio-polyurethanes ${ }^{22}$. Rigid polyurethane foams made from a polyol derived from melamine and cardanol $^{23}$. Cardanol was allowed to react with paraformaldehyde melamine and diethanolamine to yield mixed Mannich bases which were subsequently propoxylated to give the MCMP. Rigid polyurethane foams (RPUFs) were prepared using MCMP and a polyisocyanate. It was demonstrated that MCMP in molecular structure increased the thermal stability and the flame retardancy of the RPUF. New oligomers with oxamidoestercarbamidoimide, carbamide, oxamidoester and oxamide groups components obtained Zarzyka ${ }^{24}$. Added as polyols for rigid foams increased theirs thermal stability.

The aim of the research is a synthesis of new polyols, not described in any literary source, using cheap technical 2-hydroxypropane-1.2.3-tricarboxylic acid. The effect of this polyol on the properties of rigid polyurethane-polyisocyanurate foams was also tested.

\section{EXPERIMENTAL}

\section{Material and methods}

For synthesis of PUR-PIR foams used polyol Rokopol RF 551 and diisocyanate Ongromat CR 30-20. The Rokopol RF 551 polyether (polyoxypropylenehexol with 400-440 mgKOH/g hydroxyl number, molecular weight of 660) produced by Chemical Plants PCC Rokita S.A. in Brzeg Dolny. Technical diisocyanate Ongromat CR 30-20 produced in Hungary (BorsodChem), whose main component is 4.4'-diphenyl-methane-diisocyanate (MDI), were used to prepare rigid PUR-PIR foams. The density of Ongromat CR $30-20$ at $25^{\circ} \mathrm{C}$ was $1230 \mathrm{~kg} / \mathrm{m}^{3}$, viscosity was $200 \mathrm{mPa} \cdot \mathrm{s}$ and the con centration of NCO groups was $31.0 \%$. The polyether and diisocyanate were characterized according to ASTM D 2849-69 and ASTM D 1638-70 standards. The catalyst used to produce the foams was anhydrous potassium acetate (POCh Gliwice) applied in a form of 33\% solution in diethylene glycol DEG (catalyst 12) and "DABCO 33LV" (triethylenediamine, Hülls, Germany) applied in a form of 33\% solution in diethylene glycol (DEG). The foam structure stabilizer was polyoxosilanepolyoxyalkene surface-active agent „Silicone L-6900” (Witco, Sweden). Carbon dioxide formed during a reaction of water with isocyanate groups acted as a blowing agent. Liquid flame retardant i.e. „Antiblaze TMCP”, tris(2-chloro-1-methylethyl) phosphate (Albright and Wilson, Great Britain), was added to the foams. Newly produced polyester polyols E2 and E4 were added to the foams in the amount of $0.1-0.5$ equivalent in relation to the amount of Rokopol RF 551, whose content was reduced to $0.9-0.5 \mathrm{R}$.

\section{Acquiring new polyester polyols}

An esterification reaction was performed to obtain $135 \mathrm{~g}$ of butane-1.4-diol (BD) from $96 \mathrm{~g}$ of 2-hydroxy-1.2.3propanetricarboxylic acid (citric acid), $0.1 \%(0.24 \mathrm{~g}$ ) of all catalyst was added in relation to the amount of the glycol and the acid. A tetraisopropyl titanate was used as a catalyst for synthesis I which resulted in obtaining polyol E6. Tyzor TPT produce by Du Pont is the market name for the used catalyst, Lewis acid, the tetraisopropyl titanate. It is a colorless, yellowish liquid, highly sensi- 
tive to moisture with freezing temperature of $19^{\circ} \mathrm{C}$, it crystallizes at low temperatures (but after re-raising the temperature it is suitable for use). It is characterized by: content of $\mathrm{TiO}_{2}-28.1 \%$, molecular mass $-284 \mathrm{~g} / \mathrm{mole}$, density at $20^{\circ} \mathrm{C}-950 \mathrm{~kg} / \mathrm{m}^{3}$, viscosity $-3.5 \mathrm{mPa} \cdot \mathrm{s}$, boiling point $-232^{\circ} \mathrm{C}$. It is miscible in the majority of organic solvents and is easily soluble in water.

Synthesis II, the tin(II) acetate was used as a catalyst (E7 polyol synthesis). It is produced by Evonik Goldschmidt $\mathrm{GmbH}$ company. It is a yellow liquid with melting temperature below $21.6^{\circ} \mathrm{C}$ and boiling point of above $400^{\circ} \mathrm{C}$, however its combusting temperature is above $200^{\circ} \mathrm{C}$.

Synthesis III was performed with the use of sulfuric(IV) acid (E8 polyol). A concentrated $\mathrm{H}_{2} \mathrm{SO}_{4}(96 \%)$, produced by POCH Polskie Odczynniki Chemiczne S.A., Gliwice, was used.

Reaction IV was performed without the use of a catalyst, obtaining E9 polyol.

The esterification was conducted in a three-neck glass flask (500 $\mathrm{ml}$ vol.) equipped with reflux condenser, thermometer, stirrer and Dean-Stark head. The reaction took place in xylene medium. The generated water was collected in the head. Each flask was heated in an electric bath until the acid dissolved. The citric acid dissolved in $20 \mathrm{~min}$. at $85^{\circ} \mathrm{C}$. The reaction time was measured from the moment of mixture boiling in the flask (ca. $125^{\circ} \mathrm{C}$ ), i.e. $30 \mathrm{~min}$. after mixing the components. The temperature of the reaction increased in the range of $125-145^{\circ} \mathrm{C}$ and then dropped to $120^{\circ} \mathrm{C}$. Near the end, when the water was generating slowly, the catalyst was added. The parameters of the esterification are presented in Table 1.

Every 30 minutes the quantity of the generated water was measured. Reactions were controlled by measuring the acid number and temperature in $30 \mathrm{~min}$. intervals. The $\mathrm{pH}$ of the final product was also tested. The product delaminated into two layers: upper - xylene and lower - polyol. Xylene was distilled off into Deana-Stark head. The residual xylene was evaporated in a vacuum drier. The properties of produced E6, E7, E8 and E9 polyols were tested. Then the product of reaction I, i.e. E6 polyol, was used to synthesize rigid PUR-PIR foam.

\section{Examining the properties of newly obtained polyols}

In order to examine the usefulness of newly obtained polyester polyols for the synthesis of polyurethanepolyisocyanurate (PUR-PIR) foams, their properties were determined according to the standards in force.

The presence of citric acid in the obtained product was determined by dissolving $0.5 \mathrm{~g}$ of the tested sample in
$5 \mathrm{~cm}^{3}$ of water. Then, the solution was neutralized with $1 \mathrm{~mol} / \mathrm{dm}^{3} \mathrm{NaOH}$ and $10 \mathrm{~cm}^{3}$ of $25 \%$ solution $\mathrm{CaCl}_{2}$ were added. The mixture was heated to its boiling point. As a result of the reaction, white precipitate was formed that indicated the presence of the citric acid.

The FTIR analysis was performed using a Vector spectrophotometer produced by Brücker company. The hydroxyl and acid values were determined in compliance with the WT/06/07/PURINOVA internal standard of Purinowa company in Bydgoszcz. The color was established in an organoleptic manner. For pH measurements, a microcomputer CP-551 pH meter was used. The density was determined at $25^{\circ} \mathrm{C}$ according to PN-92/C-04504 and the viscosity was measured with Höeppler viscometer at $25^{\circ} \mathrm{C}$ according to PN-EN ISO 12058-1.

The water quantity was tested using Karl Fisher method in compliance with the PN-81/C-04959 standard.

\section{Preparation of PUR-PIR foams}

The foams were prepared on a laboratory scale from two-component system with the equivalent ratio of $\mathrm{NCO}$ to $\mathrm{OH}$ groups equal to $3: 1$ using one-stage method. Component A was obtained by thorough mixing (stirrer rotation speed - $1800 \mathrm{rpm}$, mixing time - $10 \mathrm{~s}$.) of Rokopol RF551, which was subtracted to add the new E6 polyol (Table 2). The following catalysts were added to the synthesis in constant values: DABCO $-0.9 \%$ of the mass $(2.9 \mathrm{~g})$, Catalyst $12-2.1 \%$ of the mass $(6.7 \mathrm{~g})$, an agent reducing combustibility Roflam $\mathrm{P}-15 \%$ of the mass (47.5 g), Silicon Tegostab 8460 surface-active agent $-1.5 \%$ of the mass $(4.7 \mathrm{~g})$ and a blowing agent (water $-0.7 \mathrm{R}$ ). The quantity of water was reduced by the quantity of water in the new polyol (E6), from $3.15 \mathrm{~g}$ (P6.0 foam) to $2.27 \mathrm{~g}$ (P6.5 foam). Ongromat CR 30-20 3.7 R (250.7 g) was Component B. Both components were mixed (speed - $1800 \mathrm{rpm}$, time $-10 \mathrm{~s}$ ) in an appropriate mass ratio and poured into an open metal rectangular mould with the dimensions of $195 \times 195 \times 240 \mathrm{~mm}$. A series of foam was obtained this way: P6 (from P6.0 to P6.5) with E6 ester. The synthesis of the foam series was repeated twice.

Times of foam processing were measured during foaming i.e. start time, time of expansion and time of gelation (always counted from the moment of mixing of all components), i.e.:

- start time (to achieve a state of cream, which is the start of volume expansion foam),

Table 1. Parameters of esterification of polyols E6-E9

\begin{tabular}{|c|c|c|c|c|c|c|}
\hline \multirow{2}{*}{$\begin{array}{l}\text { Name of } \\
\text { compound }\end{array}$} & \multirow[t]{2}{*}{ Catalyst [0.1\%] } & \multirow{2}{*}{$\begin{array}{c}\text { Time of } \\
\text { reaction [h] }\end{array}$} & \multicolumn{2}{|c|}{ The amount of obtained product [g] } & \multicolumn{2}{|c|}{ The amount of distilled water $\left[\mathrm{cm}^{3}\right.$} \\
\hline & & & theoretical & practical & theoretical & practical \\
\hline E6 & Tyzor TPT & 6 & 204 & 170 & 27 & 45 \\
\hline E7 & tin(II) acetate & 7.5 & 204 & 164 & 27 & 54 \\
\hline E8 & sulfuric(VI) acid & 4 & 204 & 200 & 27 & 50 \\
\hline E9 & - & 2.5 & 204 & 203 & 27 & 40 \\
\hline
\end{tabular}

Table 2. Properties of polyols E6-E9

\begin{tabular}{|l|c|c|c|c|c|c|c|c|}
\hline Compound & $\begin{array}{c}\text { Viscosity at } \\
25^{\circ} \mathrm{C}[\mathrm{mPa} \cdot \mathrm{s}]\end{array}$ & $\begin{array}{c}\text { Density at } \\
25^{\circ} \mathrm{C}\left[\mathrm{kg} / \mathrm{m}^{3}\right]\end{array}$ & $\begin{array}{c}\text { Hydroksyl } \\
\text { number } \\
{[\mathrm{mgKOH} / \mathrm{g}]}\end{array}$ & $\begin{array}{c}\text { Acid number } \\
{[\mathrm{mg} \mathrm{KOH} / \mathrm{g}]}\end{array}$ & $\begin{array}{c}\text { State of } \\
\text { aggregation }\end{array}$ & $\mathrm{pH}$ & $\begin{array}{c}\text { Amount of } \\
\text { water }[\%]\end{array}$ \\
\hline E6 & 14552 & 927 & 496 & 28 & liquid & 3.2 & $\begin{array}{c}\text { bright straw, } \\
\text { transparent }\end{array}$ & 3.1 \\
\hline E7 & - & 1033 & - & 16 & solid & 3.0 & milk & - \\
\hline E8 & - & 1051 & - & 19 & solid & 3.1 & colorless & - \\
\hline E9 & - & 979 & - & 92 & solid & 3.1 & straw & - \\
\hline
\end{tabular}


- increase the time until you have the maximum foam volume,

- total gel time until the free surface of the foam stops to attach a clean glass rod.

\section{Assessing the properties of rigid PUR-PIR foams}

After removing them from the mould, the obtained foams were thermostated for $4 \mathrm{~h}$ at the temperature of $120^{\circ} \mathrm{C}$. They were then seasoned for $48 \mathrm{~h}$ at temperature of $20 \pm 4^{\circ} \mathrm{C}$, cut into pieces and their basic properties were determined in compliance with the standards in force. The following properties were determined: the structure of the foams (Axiotech Carl Zaiss optical microscope Hal 100, simultaneously transmitted and reflected light, 5x magnification), compressive strength (Tira Test 2200 tensile testing machine, ISO 844:1993: DIN 53420 standard), brittleness (ASTM C-421-61 standard), density (ISO 845-1988), thermal resistance (derivatograph operating in Paulik-Paulik Erdey system, MOM - Budapest), heat conductivity („FOX 200” apparatus, Lasercomp), percentage of closed cells (PN-ISO 4590:1994), water absorbing capacity (DIN 53433), flammability (horizontal test according to the PN-78 C-05012 standard), shortened chimney test (Butler's vertical test, ASTM D3014-73), flammability using a Vigo V-20E2-25 thermal imaging camera equipped with $\mathrm{HgCdTe}$ thermoelectrically cooled detector, oxygen index (ASTM D 2863-1970). The chemical structure of the foams was determined using IR spectroscopy (Brücker Vector spectrophotometer).

Moreover, the products of the thermal decomposition of the foams without the access of air at $300^{\circ} \mathrm{C}$ were determined using Trace 2200 gas chromatograph. The foams were decomposed in three-neck flask without air access at $300^{\circ} \mathrm{C}$. The chromatograph parameters were identical as in the case of polyesters examination (as described above).

\section{RESULTS AND DISCUSSION}

\section{Synthesis and characterisation of polyols}

As a result of the reaction between butane-1.4-diol (1.4-BD) and 2-hydroxypropane-1.2.3-tricarboxylic (citric) acid with the use of $0.1 \%$ catalyst: Tyzor TPT (for E6) or tin(II) acetate (for E7) or sulfuric(IV) acid (for E8) or without the use of a catalyst (for E9), four polyols were obtained: E6 (synthesis I), E7 (synthesis II), E8 (synthesis III) and E9 (synthesis IV). The theoretical stoichiometric course of the synthesis of mentioned polyols was illustrated in one joint reaction on the scheme 1:

The structure of the new compounds was verified by conducting an IR analysis. As a result of the FTIR analysis of the new E compounds, FTIR spectra were produced (sample spectrum of E6 compound shown on Fig. 1) which show an absorption wave at the 1380 $\mathrm{cm}^{-1}$ wavelength (1) related to $\mathrm{C}-\mathrm{O}-\mathrm{H}$ carboxyl acids. The tremor at $1750-1735 \mathrm{~cm}^{-1}$ (2) wavelength, is the $\mathrm{C}=\mathrm{O}$ wave (characteristic for aliphatic esters). The $3300-2500 \mathrm{~cm}^{-1}$ (3) range, is the stretching tremor wave for $\mathrm{O}-\mathrm{H}$ group. A strong $\mathrm{C}-\mathrm{O}$ wave related to esters is present at the $1075 \mathrm{~cm}^{-1}$ (5) range. Moreover, the spectrum shows a high-concentration $\mathrm{C}-\mathrm{O}$ bond in the ester at $220 \mathrm{~cm}^{-1}$ (4), and also a wave at $1073 \mathrm{~cm}^{-1}$ (7) related to I-tier hydroxyl group and at $1036 \mathrm{~cm}^{-1}$ related to C-O-C ether bonds (8). The tremor at $2954 \mathrm{~cm}^{-1}$ (6) range are stretching tremors of the methyl group.

The presence of ether bonds (8) (and the higher amount of distilled water than expected, based on the reaction's stoichiometry) indicates the ability for esterification (creating esters) between the hydroxyl group of the citric acid and the used glycol. The value of acidic number of the obtained products (Table 3 ) also indicated the presence of not-reacted carboxyl groups (1).

Therefore, a more approximate structure of the obtained product E6 can be proposed (scheme 2). In the calculation of the hydroxyl value it indicates that the molecule of the polyol contains 5 moles of citric acid. The model shows that this molecule is about 13 moles of $\mathrm{OH}$ groups. The calculations show that this molecule should be $17 \mathrm{OH}$ groups. However, this is impossible. We conclude that part of these groups is derived from the water contained in the polyol $(3.1 \%)$, which confirms NMR (OH groups are represented by signal $3.3 \mathrm{ppm}$ ).

In which: $\mathrm{R}=\left(\mathrm{CH}_{2}\right)_{4}$

Taking into account the fact that after the esterification of E7-E9, the obtained products were rubbery, it can be deducted that along with the citrate creation reactions, also reactions of partial cross-linking take place, especially when using a catalyst. In the HNMR (Fig. 2) spectrum

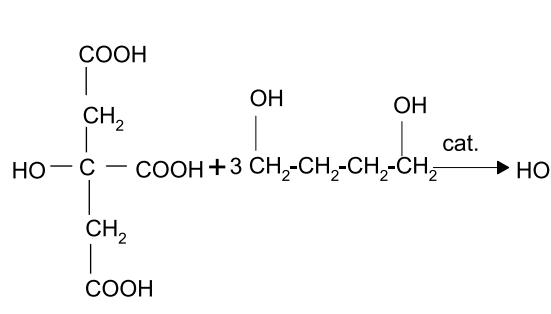

0

$\mathrm{C}-\mathrm{O}-\mathrm{CH}_{2}-\mathrm{CH}_{2}-\mathrm{CH}_{2}-\mathrm{CH}_{2}-\mathrm{OH}$

$\mathrm{CH}_{2} \mathrm{O}$

$-\mathrm{C}-\mathrm{C}-\mathrm{O}-\mathrm{CH}_{2}-\mathrm{CH}_{2}-\mathrm{CH}_{2}-\mathrm{CH}_{2}-\mathrm{OH}+3 \mathrm{H}_{2} \mathrm{O}$

$\mathrm{CH}_{2}$

$\mathrm{C}-\mathrm{O}-\mathrm{CH}_{2}-\mathrm{CH}_{2}-\mathrm{CH}_{2}-\mathrm{CH}_{2}-\mathrm{OH}$

0

Scheme 1. Synthesis of E6

2-hydroxypropane- $1.4-\mathrm{BD}$

E6

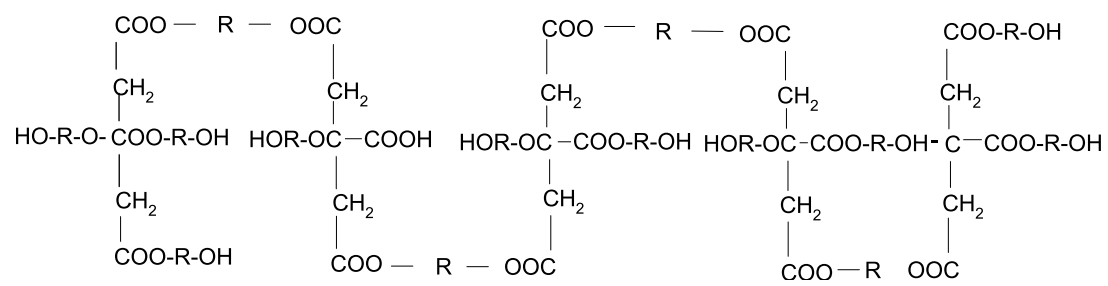

Scheme 2. Condensation between citric acid and butane-1.4-diol 


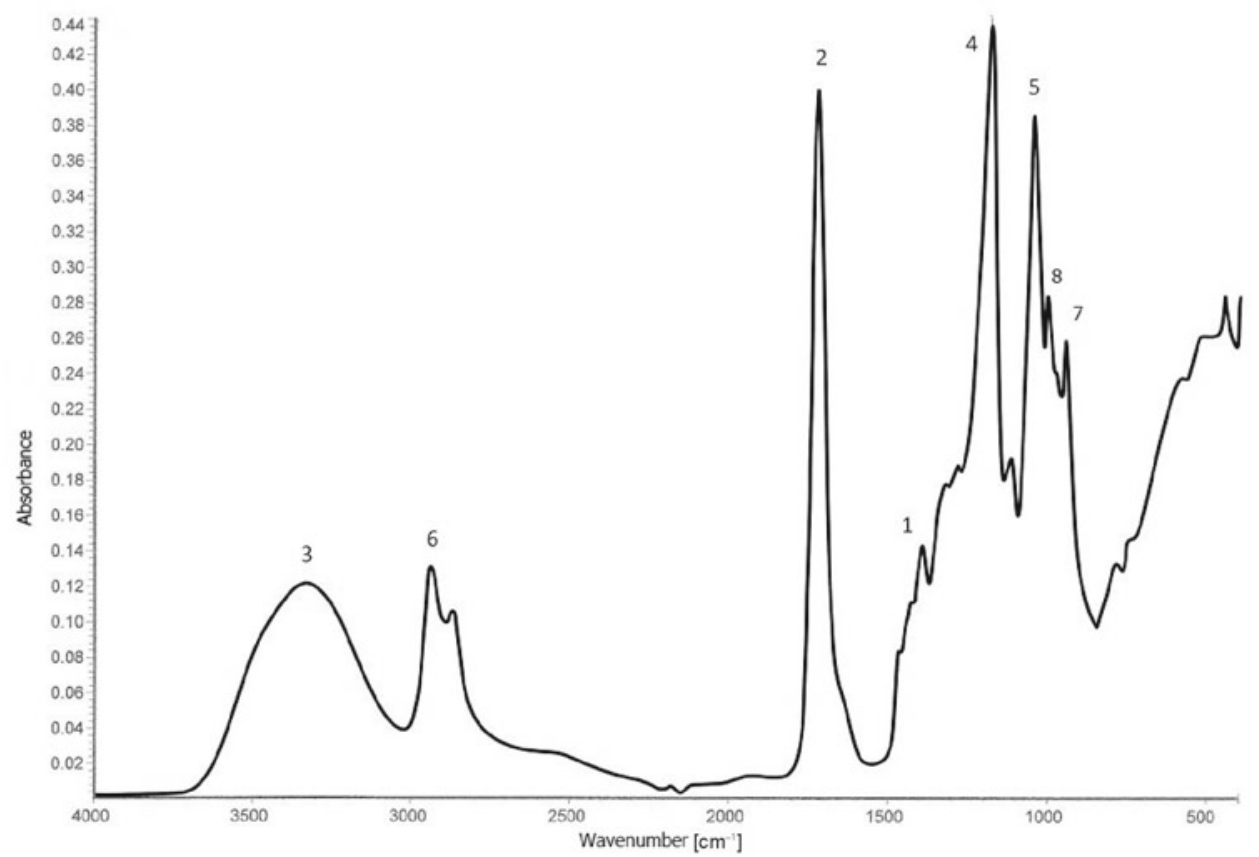

Figure 1. FTIR analysis of the E6 polyol (description in the text)

there is a visible signal with 12.38 ppm chemical shift, indicating the presence of not-reacted carboxyl group. Hydroxyl groups $\mathrm{OH}$ are represented by $5.6 \mathrm{ppm}$ signal which fades after adding $\mathrm{D}_{2} \mathrm{O}$ (heavy water) to the composition. In the structure methyl groups are represented by signals at $2.47 \mathrm{ppm}$ and $2.48 \mathrm{ppm}$. Whereas, the signal of the methyl group directly connected with hydroxyl group, has $3.3 \mathrm{ppm}$ shift. HNMR confirms the existence of bonds of $-\mathrm{O}-\mathrm{CH} 2-\mathrm{CH} 2-\mathrm{CH} 2-\mathrm{CH} 2$ - $\mathrm{O}$ - (signals at $4.0 \mathrm{ppm}$ and $1.5 \mathrm{ppm}$ ).

Based on the organoleptic features (state of matter), an initial selection of the usefulness of the polyols for further synthesis was determined. The reaction course varied from $2.5 \mathrm{~h}$ to $7.5 \mathrm{~h}$ (Table 1 ). The obtained esters dissolve in hot water and acetone, they barely dissolve in ethanol, and the E7 does not dissolve in ethanol.

E7 product, obtained with the use of tin(II) acetate, had a form of a rubbery solid matter with a milky color, density of $1033 \mathrm{~kg} / \mathrm{m}^{3}$ and $16 \mathrm{mgKOH} / \mathrm{g}$ acid number (Fig. 1). The reaction took $7.5 \mathrm{~h}$.

Obtained with the use of sulfuric(IV) acid, E8 polyester polyol was a gelatinous, colorless solid matter with 1051 $\mathrm{kg} / \mathrm{m}^{3}$ density and $\mathrm{pH}$ of 3 . The acid number of E8 equals $19 \mathrm{mgKOH} / \mathrm{g}$. The water was no longer generated after 4 hours and the reaction was stopped after that time. Both E7 and E8 esters did not show any usefulness in producing rigid PUR-PIR foams.

The synthesis of the polyester polyol without the use of a catalyst resulted in E9 product which was useless in foam preparation. The reaction ended after 2.5 hours and resulted in a resin solid matter with a straw-yellow color and $92 \mathrm{mgKOH} / \mathrm{g}$ acid number (Fig. 3). The density of E9 polyol was $979 \mathrm{~kg} / \mathrm{m}^{3}$ (Table 2). Due to the resulting state of the matter, its viscosity could not be tested.

The product that resulted from the esterification of citric acid (2-hydroxy-1.2.3-propanetricarboxylic acid) with butane-1.4-diol (polyol E6) with the use of $0.1 \%$ catalyst (Tyzor TPT) shows its usefulness as a polyol for production of rigid PUR-PIR foams. It is characterized by $496 \mathrm{mgKOH} / \mathrm{g}$ hydroxyl number and $28 \mathrm{mgKOH} / \mathrm{g}$ acid number. It contained $3.1 \%$ of water and its $\mathrm{pH}$ was 3.2 (Table 2).

Varied reaction time of the esters is caused by the addition of different types of catalysts. The state of the obtained matter (liquid, gelatin, solid matter, resin) depended on the speed of the reaction (therefore, on the catalyst).

Water was being generated the quickest during obtaining E7 and E8 polyols (Fig. 4). The largest amount of water was generated during E7 polyester polyol synthesis (the reaction took the longest - 7.5 hours). During E9 synthesis, initially, the water was being generated slowly (during the first hour), then the amount of water generated in the Dean-Stark's head increased rapidly, which resulted in obtaining resin product after 2.5 hours of the reaction. The water during E6 polyester polyol synthesis reaction was being generated the slowest which resulted in a liquid product. E7-E9 products was solid. The tetraisopropyl titanate catalyst (Tyzor TPT) was the most useful (from all catalysts) in the esterification reaction. Thanks to it, the water was generated at optimal speed and the end product was of the right consistency.

The syntheses of individual polyols were conducted at different temperatures (Fig. 5). The addition of sulfuric(IV) acid (synthesis III, polyol 8) significantly

Table 3. Recipe used for preparation of series of foams P6.0-P6.5

\begin{tabular}{|c|c|c|c|c|c|c|c|c|}
\hline Compound & Equivalent & Unit & P6.0 & P6.1 & P6.2 & P6.3 & P6.4 & P6.5 \\
\hline Rocopol RF 551 & $\mathrm{R}$ & g & $\begin{array}{c}1 \\
66.8\end{array}$ & $\begin{array}{r}0.9 \\
60.1\end{array}$ & $\begin{array}{r}0.8 \\
53.4\end{array}$ & $\begin{array}{r}0.7 \\
46.7\end{array}$ & $\begin{array}{r}0.6 \\
40.0\end{array}$ & $\begin{array}{r}0.5 \\
33.4\end{array}$ \\
\hline Polyol E6 & $\mathrm{R}$ & $g$ & $\begin{array}{l}0 \\
0\end{array}$ & $\begin{array}{l}0.1 \\
6.60\end{array}$ & $\begin{array}{c}0.2 \\
13.26\end{array}$ & $\begin{array}{c}0.3 \\
19.90\end{array}$ & $\begin{array}{c}0.4 \\
26.54\end{array}$ & $\begin{array}{c}0.5 \\
33.17\end{array}$ \\
\hline Water & $\mathrm{R}$ & $g$ & $\begin{array}{l}0.7 \\
3.15\end{array}$ & $\begin{array}{l}0.7 \\
2.97\end{array}$ & $\begin{array}{l}0.7 \\
2.79\end{array}$ & $\begin{array}{l}0.7 \\
2.62\end{array}$ & $\begin{array}{l}0.7 \\
2.45\end{array}$ & $\begin{array}{l}0.7 \\
2.27\end{array}$ \\
\hline
\end{tabular}




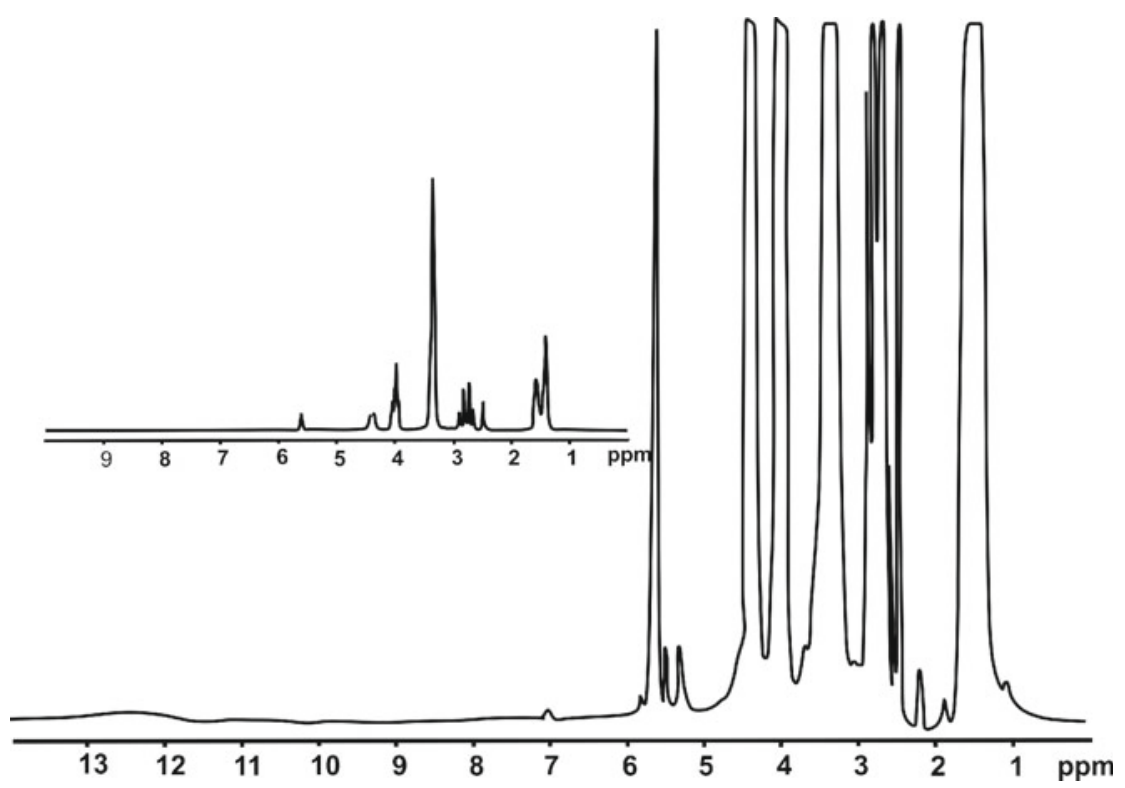

Figure 2. HNMR analysis of the E6 polyol

decreased the reaction temperature in relation to other catalysts by ca. $15^{\circ} \mathrm{C}$ in the first hour of the synthesis. After 2 hours of the synthesis, the difference between synthesis III and IV (polyester 8 and 9) was $20^{\circ} \mathrm{C}$, between III and II it was $25^{\circ} \mathrm{C}$ and between III and I is was $28^{\circ} \mathrm{C}$. In the fourth hour of the reaction the temperature of the synthesis with the use of $\mathrm{H}_{2} \mathrm{SO}_{4}$ was lower by about $50^{\circ} \mathrm{C}$ in comparison to the temperature of the synthesis with the use of tin(II) acetate (polol 7) or Tyzor (polyol 6). At the end of individual reactions the reaction temperature dropped to $140^{\circ} \mathrm{C}$ (synthesis I), to $120^{\circ} \mathrm{C}$ (synthesis III) and to $105^{\circ} \mathrm{C}$ (synthesis III). In the case of synthesis IV, the reaction temperature stayed at $142^{\circ} \mathrm{C}$ (the reaction ended after 2.5 hours because a resin solid matter precipitated).

The acid number $\left(\mathrm{L}_{\mathrm{k}}\right)$ of the obtained new compounds was $28 \mathrm{mgKOH} / \mathrm{g}$ (E6 polyol), $19 \mathrm{mgKOH} / \mathrm{g}$ (E8 polyol) and $16 \mathrm{mgKOH} / \mathrm{g}$ (E6 polyol). Only the product obtained without the use of a catalyst had a high acid number of 92 $\mathrm{mgKOH} / \mathrm{g}$. Despite the high $\mathrm{L}_{\mathrm{k}}$ value of the $\mathrm{E} 9$ product, the synthesis had to be stopped because the water was no longer being generated and the reaction could not be continued (the resin blocked stirrer's functionality).

\section{Preparation and properties of rigid foams}

The second part of the experiment consisted of synthesis of rigid polyurethane-polyisocyanurate foams using E6 polyester polyol in the amount of 0.1-0.5 equivalent in

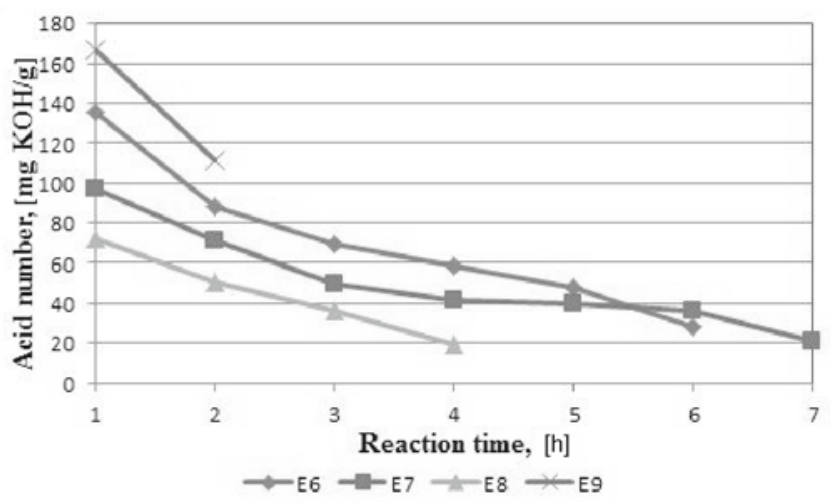

Figure 3. The dependency between the acid number and the E6-E9 polyols reaction time compliance with the formula (Table 3). The effect of this polyol on the properties of the series of 6.0-6.5 foams was tested. The measured processing times during foam preparation time have the tendency to elongate (Table 4). The start time increases in the range of $10 \mathrm{~s}$ (foam 6.0) to $20 \mathrm{~s}$ (foam 6.5), expansion time elongates from $31 \mathrm{~s}$ (6.0) to $49 \mathrm{~s}(6.5)$ and gelation time increases from $28 \mathrm{~s}$ (6.0) to $90 \mathrm{~s}(6.5)$. The elongation of processing times is caused by the addition of new polyol into foams and simultaneous extraction of Rocopol FR 551 from them. It was observed that with foams 6.0 and 6.1, the expansion time is shorter than the start time, for foam 6.3 they are identical and with the increasing amount of the new polyol, they are reversing, therefore in foams 6.4 and 6.5 the gelation time is longer than the expansion time.

IR analysis of foams (Fig. 6) showed presence of isocyanurate bond $\left(1736 \mathrm{~cm}^{-1}\right)$ and urethane bond (2969-2915 $\mathrm{cm}^{-1}$ ) in foams. Moreover, hydroxyl group $\mathrm{OH}$ was observed within the range from 3136 to $3360 \mathrm{~cm}^{-1}$.

The brittleness of the foam modified with the polyol (its $0.5 \mathrm{R}$ addition) decreases more than twofold (from $13.7 \%$, foam P6.5) in comparison to the foam not containing polyol $(28.4 \%$, foam P6.0) - Figure 7. The addition of the new ester polyol caused a decrease in foams' compressive strength from $185 \mathrm{kPa}$ (foam 6.0) to $69 \mathrm{kPa}$ (foam 6.5) - Table 5. The strength should increase with the apparent density of the foams, however such correlation does not occur. The apparent density

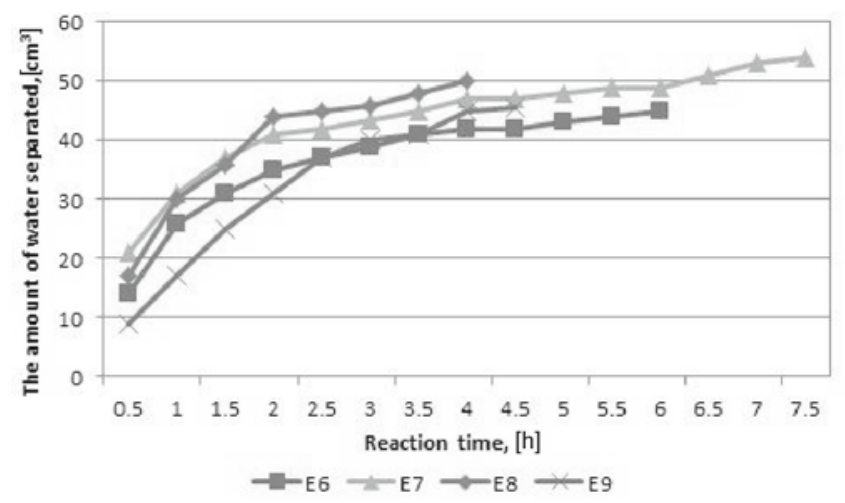

Figure 4. The dependency between the amount of extracted water in the reaction and the E6-E9 polyols extraction time 


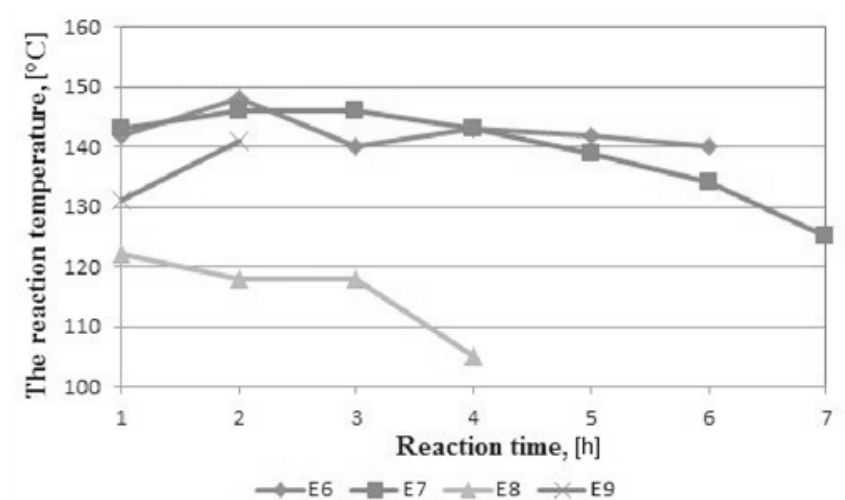

Figure 5. The dependency between the reaction temperature and the E6-E9 polyols extraction time

changes from $36.96 \mathrm{~kg} / \mathrm{m}^{3}$ (foam P6.0 without the new polyol) to $60.35 \mathrm{~kg} / \mathrm{m}^{3}$ (foam P6.5 containing $0.5 \mathrm{R}$ of the new polyol). This is cause by the fact, that the foam cell walls are thickening with the raising amount of the new compound in the foams (Fig. 8-9). Despite the lowering quantity of closed cells in the foam, their heat conductivity slightly decreases from $35.54 \mathrm{~mW} / \mathrm{m} \cdot \mathrm{K}$ to $33.91 \mathrm{~mW} / \mathrm{m} \cdot \mathrm{K}$. This beneficial relation could be caused by the significant increase of the apparent density of the foam from $36.96 \%$ (foam P6.0) to $60.35 \%$ (foam P6.5). The changing structure of the series of P6.0-P6.5 foams (Figures 8 and 9) has also an influence on the poorer heat conductivity. The picture of the structure of foams cut in the direction opposite to the expansion direction (Figure 9) shows that the cells are spherical. It indicates that the addition of the new polyol does not in any way disturb the free side expansion in the mould. Also, the amount of the surface-active agent was matched properly.

On the structure picture taken according to the foam expansion, a minimal elongation of cells can be seen in the case of P6.1 foam. The foaming process affected the cell shape. The gelation time of this foam was shorter than its expansion time. The processing parameters (gelation and expansion) shaped the cells of P6.1 foam in a way that they were subjected to a slight elongation. In the case of that P6.1 foam it is visible that some cells
Table 4. The time series of foam processing P6.0-P6.5

\begin{tabular}{|l|c|c|c|}
\hline Foam & Start time [s] & Growth time [s] & Gelation time [s] \\
\hline 6.0 & 10 & 31 & 28 \\
\hline 6.1 & 12 & 32 & 30 \\
\hline 6.2 & 13 & 33 & 33 \\
\hline 6.3 & 15 & 42 & 41 \\
\hline 6.4 & 17 & 45 & 85 \\
\hline 6.5 & 20 & 49 & 90 \\
\hline
\end{tabular}

ruptured and formed one big cell (Figure 8). It can be explained by higher pressure in the mould caused by faster foam gelation in relation to its expansion. The P6.4 foam structure (and also P6.5 not captured in the picture) shows that its walls are thicker than walls of other foams. The observed tendency for cell wall thickening may be the result of increasing foam gelation time. In the figure 5 of a microscope examination according to the expansion direction, it can be seen that the shape of P6.0-P6.2 foam cells is vertically elongated and the shape of P6.4 and P6.5 foam cells is spherical. The addition of new polyol into the foam causes the cell height to be lower and, at the same time, the pore walls to be thicker.

Changing cell shape from elongated into spherical results in the foam's higher water absorption, from $0.58 \%$ vol. to $1.28 \%$ vol. However, it is lower than the absorptivity of the foam without the new polyol (P6.0

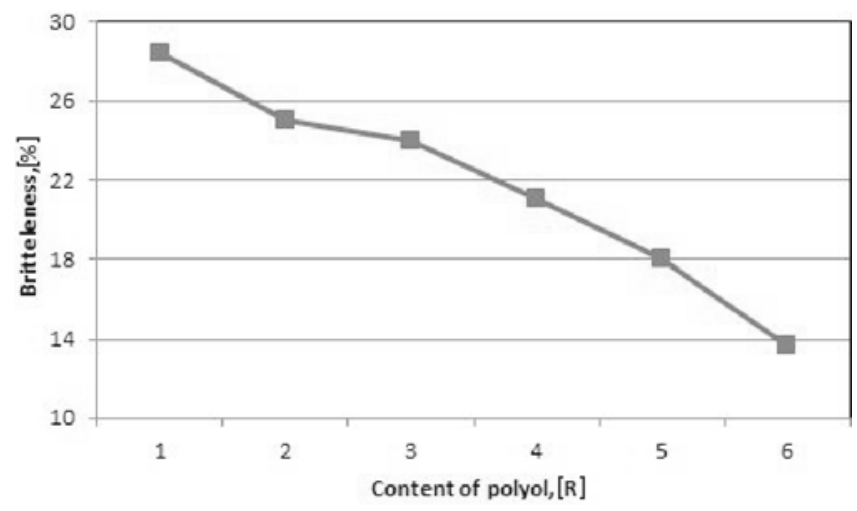

Figure 7. The dependency between the brittleness and the amount of polyol in E6 foam

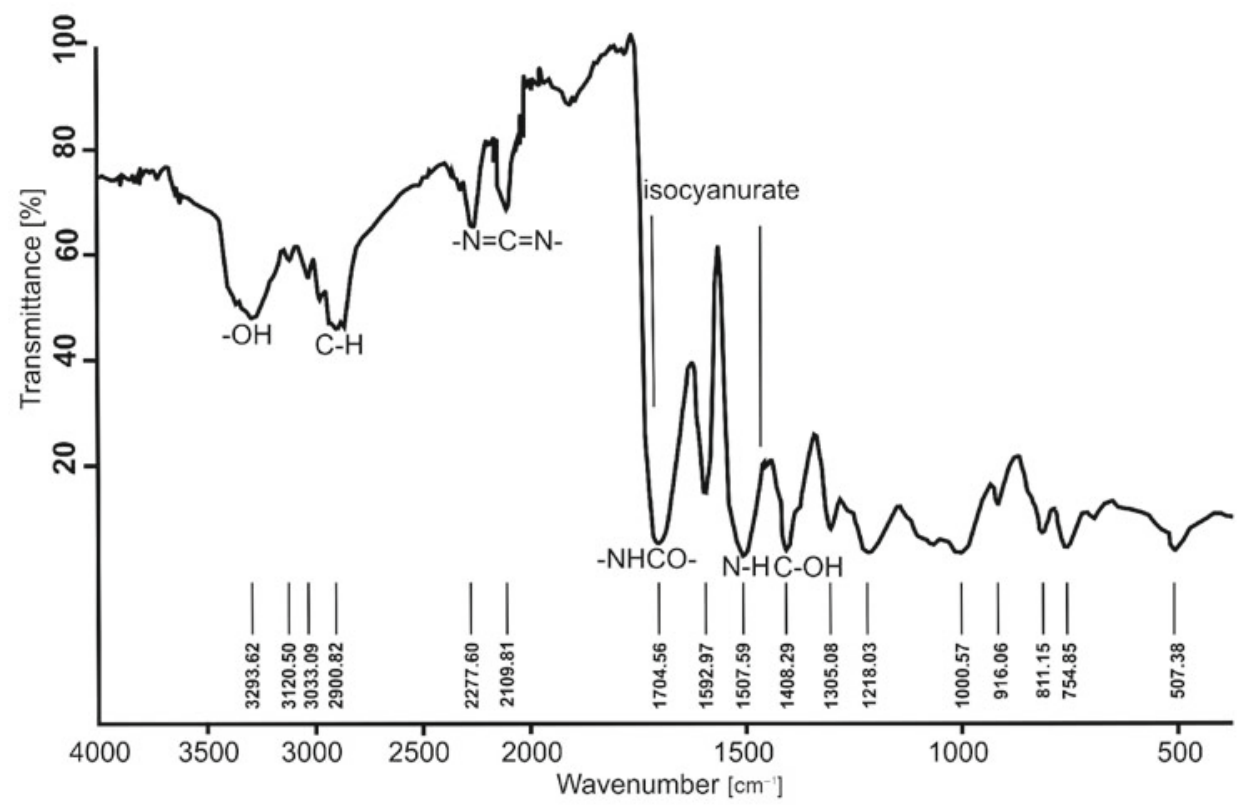

Figure 6. FTIR of the E6.1 PUR-PIR foam 
Table 5. Properties of PUR-PIR foams

\begin{tabular}{|c|c|c|c|c|c|c|c|}
\hline Foam & $\begin{array}{c}\text { Apparent } \\
\text { density }\left[\mathrm{kg} / \mathrm{m}^{3}\right]\end{array}$ & $\begin{array}{l}\text { Compressive } \\
\text { strenght }[\mathrm{kPa}]\end{array}$ & $\begin{array}{c}\text { Water } \\
\text { absorption } \\
{[\% \text { obj.] }}\end{array}$ & Fragility [\%] & $\begin{array}{c}\text { Content of } \\
\text { closed cells } \\
{[\% \text { obj.] }}\end{array}$ & $\begin{array}{l}\text { Coefficient of thermal } \\
\text { conductivity } \\
{[\mathrm{mW} / \mathrm{m} \cdot \mathrm{K}]}\end{array}$ & Retention [\%] \\
\hline P6.0 & 36.9 & 185 & 1.80 & 28 & 92 & 35.5 & 95 \\
\hline P6.1 & 37.1 & 175 & 0.58 & 25 & 89 & 33.6 & 68 \\
\hline P6.2 & 38.2 & 148 & 0.63 & 24 & 86 & 33.8 & 55 \\
\hline P6.3 & 45.1 & 103 & 0.75 & 21 & 75 & 33.9 & 50 \\
\hline P6.4 & 51.1 & 82 & 0.93 & 18 & 72 & 33.9 & 70 \\
\hline P6.5 & 60.4 & 69 & 1.28 & 14 & 69 & 33.9 & 93 \\
\hline
\end{tabular}

foam), which equals $1.8 \%$ vol. Such varied absorptivity is the result of foam structure modification caused by the addition of the new polyester polyol. Water absorption for P6.0 foam is the highest $(1.8 \%)$ due to larger surface of its cells in comparison to other foams (organoleptic analysis). The increase in water absorption in the series of P6.1-P6.5 foams is caused by the opening of the cells after the addition of E6 polyol. The closed cell count decreased along with the addition of the obtained new compound into the foam. In the foam without the E6 polyol, the close cell count equals $91.5 \%$ and decreases to $69.5 \%$ (foam containing $0.5 \mathrm{R}$ of E6 polyol) - Table 5 .

The oxygen index (OI) of foams with the new polyol is $25.6 \%$ (OI of reference foam $\mathrm{W}$ is $23.9 \%$ ). The addition of the new polyol obtained using citric acid reduced foams' flammability. The retention (remaining mass after burning) in the series of $6.1-6.5$ foams increases from $68.1 \%$ (6.1 foam containing $0.1 \mathrm{R}$ of the polyol) to $92.9 \%$ (6.5 foam containing $0.5 \mathrm{R}$ of the new polyol).

\section{CONCLUSION}

New four compounds (E6, E7, E8 and E9) were synthesized from 2-hydroxypropane-1.2.3-tricarboxylic acid and butane-1.4-diol with the use of the following catalysts: Tyzor TPT, sulfuric(IV)acid and tin(II)acetate, and without catalyst. The obtained liquid product (E6) of the esterification shows usefulness as a polyol for the production of rigid PUR-PIR foams. Its viscosity at $25^{\circ} \mathrm{C}$ is $14552 \mathrm{mPa} \cdot \mathrm{s}$ and its density at $25^{\circ} \mathrm{C}$ is 927 $\mathrm{mPa} \cdot \mathrm{s}$. It is characterized by $28 \mathrm{mgKOH} / \mathrm{g}$ acid number and $496 \mathrm{mgKOH} / \mathrm{g}$ hydroxyl number. The obtained product is transparent, straw-yellow, with $\mathrm{pH}$ of 3.2, and it contains $3.1 \%$ of water. The properties of the result-

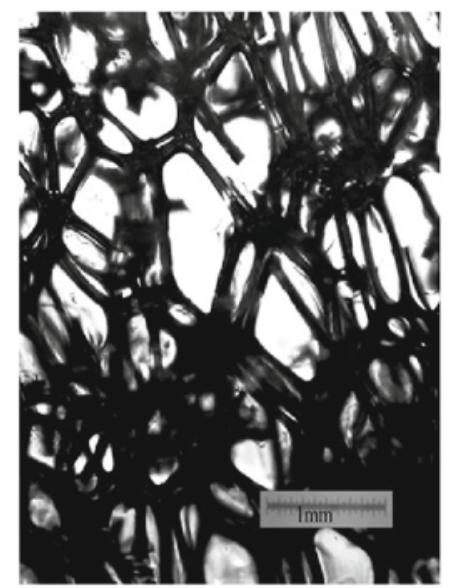

6.0

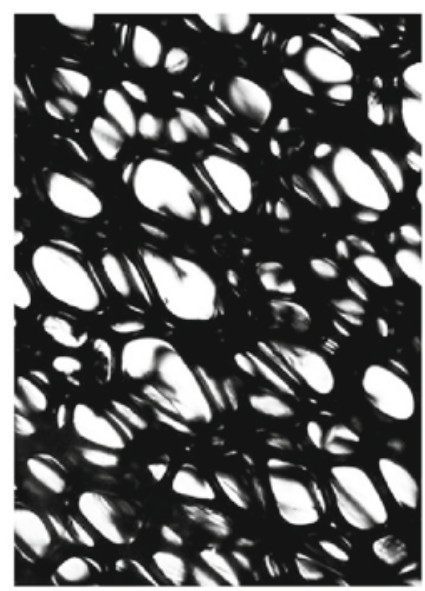

6.1

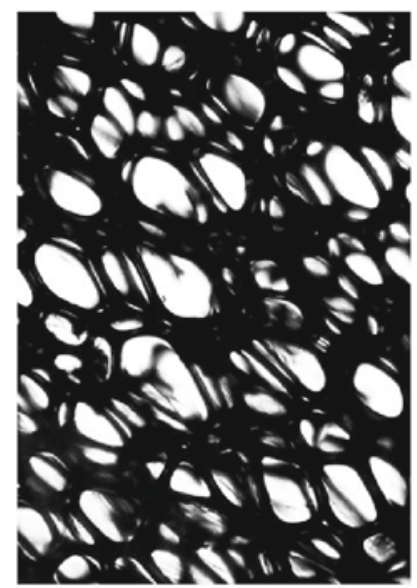

6.2

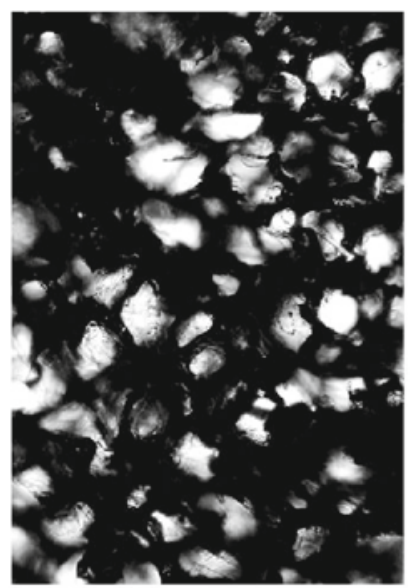

6.4

Figure 8. A photo of foam's microscopic structure taken according to the growth direction

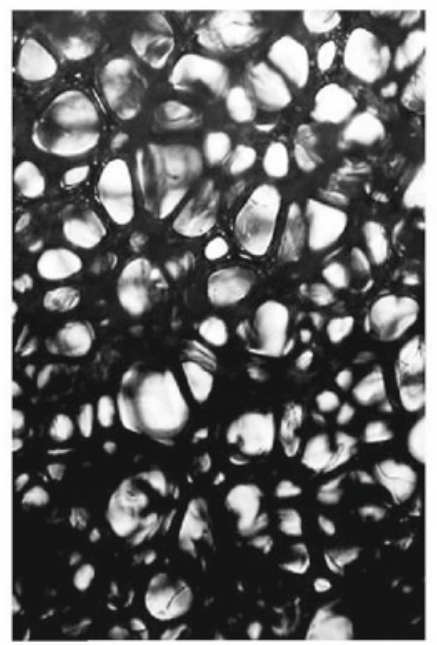

6.0

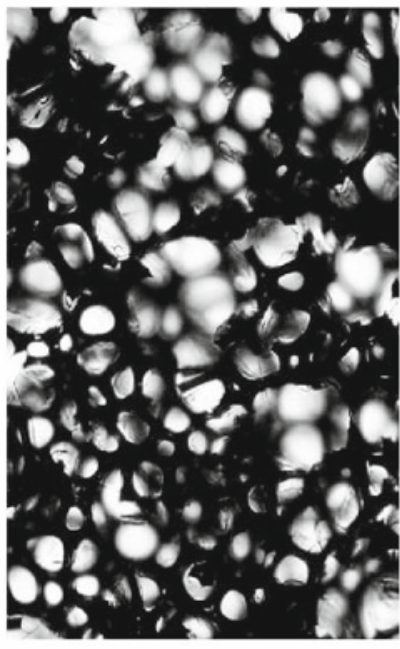

6.1

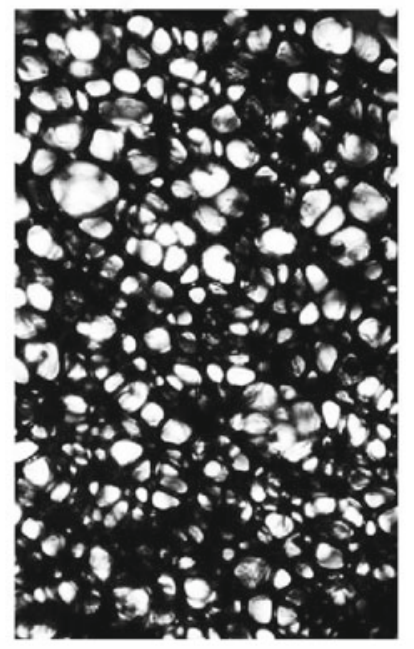

6.2

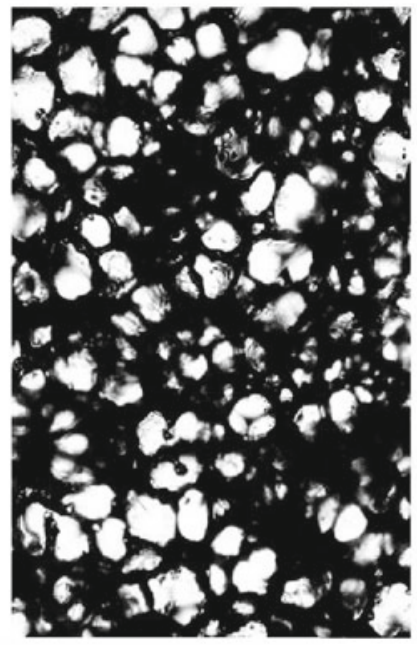

6.4

Figure 9. A photo of foam's microscopic structure taken opposite the growth direction 
ing E6 product and the properties of rigid PUR-PIR foams were examined. The newly acquired polyol was added to foams in the amount of 0.1-0.5 R (equivalent) with the simultaneous extraction of the industrial polyol (Rocopol RF 551) in the amount of 0.5-0.1R. Series of five foams P6.1-P6.5 and P6.0 foam, containing the industrial polyol in the amount of $1 \mathrm{R}$ equivalent, were obtained after two attempts. Test results show the effect of the new polyol on the properties of rigid PUR-PIR foams. The addition of polyester polyol significantly improves foam's brittleness, from $28.4 \%$ (P6.0 foam) to $13.7 \%$ (P6.5 foam). The heat conductivity decreases with the increasing amount of the polyol in the foams, from $35.5 \mathrm{~mW} / \mathrm{m} \cdot \mathrm{K}(\mathrm{P} 6.0)$ to $33.9 \mathrm{~mW} / \mathrm{m} \cdot \mathrm{K}(\mathrm{P} 6.5)$. The non-flammability of the foams also improves which is indicated by the amount of foam material left after 10 s of burning. The remaining foam material increases from $68.1 \%$ (P6.1) to $92.9 \%$ (P6.5). The newly obtained polyol causes the foam cells to open. In the foam without the new compound, the closed cells percentage equals $91.5 \%$ and in the foam with $0.5 \mathrm{R}$ of the new compound, it equals $69.5 \%$ (P6.5).

\section{LITERATURE CITED}

1. Paciorek-Sadowska, J. (2011). Studies the effect of boric acid derivatives and $\mathrm{N}, \mathrm{N}$-(dihydroxymethyl) urea on the characteristics of rigid polyurethane-polyisocyanurate foams, Kazimierz Wielki University, Bydgoszcz. [in Polish].

2. Chmiel-Szukiewicz, E. \& Lubczak, J. (2006). Reactions of trithiocyanuric acid with oxiranes. IV. Analysis of the initial stages of the synthesis of polyetherols, J. Appl. Polym. Sci. 100, 4917. DOI: 10.1002/app.23608.

3. Paciorek-Sadowska, J., Czupryński, B. \& Liszkowska, J. (2011). Application of waste products from agricultural-food industry for production of rigid polyurethane-polyisocyanurate foams. J. Porous Mater. 18, 631. DOI: 10.1007/ s10934-010-9419-8.

4. Paciorek-Sadowska, J., Czupryński, B. \& Liszkowska, J. (2011). Modification of Polymers. Status and prospects for 2011, Mater. Conf. Tempo, Wrocław. 129-134.

5. Paciorek-Sadowska, J., Czupryński, B. \& Liszkowska, J. (2012). Fire-safe polyurethanes modified with new flame retardant. Chemik 66(4), 297-306.

6. Haponiuk, J.T., Strankowski, M. \& Lazarewicz, T. (2003). DSC Study of Polyurethanes obtained from 4,4'-Bis(10Hydroxydecaoxy)biphenyl. J. Therm. Anal. Calor. 74, 609. DOI: 10.1023/B:JTAN.0000005201.12216.dd.

7. Randall, D. \& Lee, S. (editors) (2002). The polyurethanes book. Wiley Ltd.

8. Datta, J. \& Rohn, M. (2007). Glycolysis of PUR waste. Vol. I. Glycolysis agents and catalysts. Polimery 52(7-8), 579. [in Polish].

9. Datta, J. \& Rohn, M. (2007). Glycolysis of PUR waste. Vol. I. Purification and use of glycolysis. Polimery 52(9), 627. [in Polish].

10. Datta, J. \& Pasternak, S. (2005). Oligouretanols obtained by glycolysis of polyurethane foam as intermediates for the preparation of cast urethane elastomers. Polimery 50(5), 352. [in Polish].

11. Paciorek-Sadowska, J., Czupryński, B., Liszkowska, J. \& Jaskółowski, W. (2010). New organoboron polyol for the production of rigid polyurethane-polyisocyanurate foams. Vol. II. Preparation of rigid polyurethane-polyisocyanurate foams using a new organoboron polyol. Polimery 55(2), 99. [in Polish].

12. Paciorek-Sadowska, J., Czupryński, B., Liszkowska, J. \& Kotarska, K. (2012). Fire-safe polyurethane matherials modified with new flame retardant - use of new flammability test methods. Inż. Apar. Chem. 51(3), 58. [in Polish].

13. Desroches, M., Maxime Escouvois, M., Auvergnea, R., Sylvain Caillola \& Bernard Boutevina, C. B. (2012). From Vegetable Oils to Polyurethanes: Synthetic Routes to Polyols and Main Industrial Products. Polym.Rev. 52(1), 38-79. DOI: $10.1080 / 15583724.2011 .640443$.

14. Zhang, J., Tang, J.J. \& Zhang, J.X. (2015). Polyols Prepared from Ring-Opening Epoxidized Soybean Oil by a Castor Oil-Based Fatty Diol. Inter. J. Polym. Sci. Article ID 529235, 8 pages, http://dx.doi.org/10.1155/2015/529235 (on line).

15. Czub, P. (2006). The use of epoxidized soybean oil to control the viscosity of the epoxy composition. Polimery 51(11-12), 821-828. [in Polish].

16. Prociak, A. (2007). Cell structure and thermal conductivity of rigid polyurethane foams blown with cyclopentane in different moulds. Polyuret. Mag., 4, 218-24.

17. Prociak, A. (2008). Heat-insulating properties of rigid polyurethane foams synthesized with use of vegetable oils-based polyols. Polimery 53(3), 195-200.

18. Banik, I. \& Sain, M.N. (2008). Water Blown Soy Polyol-Based Polyurethane Foams of Different Rigidities. J. Reinf. Plast. Compos. 27(4), 357-373. DOI: 10.1177/0731684407083955.

19. Septevani, A.A., Evans, D.A.C., Chaleat, C., Martin, D.J. \& Annamalai, P.K. (2015). A systematic study substituting polyether polyol with palm kernel oil based polyester polyol in rigid polyurethane foam. Industrial Crops \& Products 66, 16-26. http://dx.doi.org/10.1016/j.indcrop.2014.11.053

20. Garrison, T.F., Kessler, M.R. \& Larock, R.C. (2014). Effects of unsaturation and different ring-opening methods on the properties of vegetable oil-based polyurethane coatings. Polymer 55(4), 1004-1011. DOI: 10.1016/j.polymer.2014.01.014.

21. Lee, A. \& Deng, Y. (2015). Green polyurethane from lignin and soybean oil through non-isocyanate reactions. European Polym. J., 63, 67-73. DOI: 10.1016/j.eurpolymj. 2014.11.023.

22. Datta, J. \& Głowińska, E. (2014). Effect of hydroxylated soybean oil and bio-based propanediol on the structure and thermal properties of synthesized bio-polyurethanes. Industrial Crops \& Products 61, 84-91. http://dx.doi. org/10.1016/j.indcrop.2014.06.050.

23. Zhang, M., Zhang, J., Chen, S. \& Zhou, Y. (2014). Synthesis and fire properties of rigid polyurethane foams made from a polyol derived from melamine and cardanol. Polym. Degrad. Stab., 110, 27-34. http://dx.doi.org/10.1016/ j.polymdegradstab.2014.08.009

24. Zarzyka, I. (2015). Oligomers with structural elements of imidazolidinetrione obtained from oxamic acid and oxamide: polyurethane foams modified by structural elements of imidazolidinetrione. J. Polym. Engine. 35(1), 1-10. DOI: 10.1515/polyeng-2013-0318. 